\title{
Bibliografia
}

Binnebesel, Józef, Piotr Krakowiak, Anna Janowicz, Agnieszka Paczkowska. Pozamedyczne aspekty opieki paliatywno-hospicyjnej. Gdańsk: Fundacja Hospicyjna, 2010.

Superwizja pracy socjalnej, red. Mirosław Grewiński. Warszawa: Wydawnictwo Wyższej Szkoły Pedagogicznej im. Janusza Korczaka w Warszawie, 2013.

Krakowiak, Piotr. „Cześć i historia”. W: Solidarni. Dzieje opieki paliatywno-hospicyjnej w Polsce, red. Anna Janowicz, Piotr Krakowiak, Alicja Stolarczyk, 32-63. Gdańsk: Fundacja Hospicyjna, 2015.

Strauss, Anselm, Barney Gleser. The Discovery of Grounded Theory: Strategies for Qualitative Research. New Brunswick: Routledge, 1967.

\section{Mirosław J. Szymański, Błażej Przybylski (red.), W kręgu wspótczesnych problemów edukacyjnych, Warszawa: Wydawnictwo Akademii Pedagogiki Specjalnej im. Marii Grzegorzewskiej, 2015, s. 254.}

DOl: http://dx.doi.org/10.12775/PCh.2017.021

W 2015 roku na rynku wydawniczym ukazała się książka pod redakcją Mirosława J. Szymańskiego i Błażeja Przybylskiego: $W$ kręgu współczesnych problemów edukacyjnych. Stanowi ona zbiór artykułów, których autorami są pracownicy Akademii Pedagogiki Specjalnej im. Marii Grzegorzewskiej w Warszawie oraz osoby współpracujące z tą uczelnią. Poruszają oni wiele ważnych i aktualnych problemów edukacyjnych ${ }^{1}$, nierzadko ukazując je w kontekście dokonujących się przemian społecznych, politycznych, kul-

logii Uniwersytetu Kazimierza Wielkiego w Bydgoszczy, ul. Jana Karola Chodkiewicza 30, 85-064 Bydgoszcz; e-mail: karolinakramkowska@gmail.com.

${ }^{1}$ Wybranym problemom współczesnej edukacji poświęcono w ostatnich latach m.in. następujące publikacje: Problemy edukacji jutra $w$ dobie globalizacji, red. Kazimierz Denek, Aleksandra Kamińska, Piotr Oleśniewicz (Sosnowiec: Oficyna Wydawnicza „Humanitas”, 2012); Problemy edukacji w społeczeństwie wiedzy, red. Stanisław Juszczyk (Katowice: Wydawnictwo Uniwersytetu Śląskiego, 2012); Oblicza edukacji w zmieniającym się spoleczeństwie, red. Agata Popławska (Białystok: Wydawnictwo Niepaństwowej Wyższej Szkoły Pedagogicznej, 2012); Mirosław J. Szymański, Edukacyjne problemy współczesności (Kraków-Warszawa: Oficyna Wydawnicza „Impuls”, 2014); Współczesne problemy edukacji w Polsce, 
turowych i ekonomicznych. Istotna część podjętych rozważań odnosi się do funkcjonowania różnego typu szkół oraz innych instytucji edukacyjnych, a także różnorakich inicjatyw na rzecz edukacji.

Publikacja składa się z czterech części. Pierwsza z nich - pt. „Problemy współczesnej edukacji” - to napisane w ciekawy sposób, rzetelne wprowadzenie w zasadnicze zagadnienia omawiane w pracy. Obejmuje ona dwa artykuły. W pierwszym - autorstwa Mirosława J. Szymańskiego - zostały zawarte rozważania na temat specyficznych problemów współczesnej edukacji, wynikających z rozwoju społecznego i gospodarczego oraz zachodzących obecnie dynamicznych przemian społecznych i kulturowych. Autor poświęcił szczególną uwagę kwestii równości szans edukacyjnych ${ }^{2}$ oraz problemowi zapewnienia właściwej jakości kształcenia. Co ważne, podkreślił potrzebę wypracowania nowych, oryginalnych koncepcji polityki oświatowej, a także podejmowania systematycznych działań edukacyjnych na miarę potrzeb i wyzwań współczesnego świata. Trudno nie zgodzić się z jego opinią, że ,współczesne problemy edukacyjne tylko częściowo są całkowicie nowe. Pozostałe wciąż stanowią swoistą odmianę od dawna znanych trudności i niepowodzeń w realizacji zamierzeń polityki oświatowej oraz pracy dydaktyczno-wychowawczej szkół i nauczycieli” (s. 22). Próby rozwiązywania tych problemów nie przyniosą jednak pożądanego skutku, jeśli podejmowane działania będą miały charakter pozorny. Drugi artykuł przygotowany przez Stefana M. Kwiatkowskiego - dotyczy problematyki relacji pomiędzy szkołami zawodowymi a ich otoczeniem zewnętrznym (w tym przede wszystkim pracodawcami) ${ }^{3}$. Uczony, skupiając się na współpracy i jej różnorakich odmianach, wskazał na zasadnicze obszary, w których może urzeczywistniać się partnerstwo społeczne na rzecz kształcenia zawodowego. W jego przekonaniu partnerstwo stanowi fundament wszelkiej współpracy. Oznacza ono „równoprawne postrzeganie swoich praw i obowiązków względem uczniów i absolwentów szkół zawodowych. Jest to konstytutywny element społeczeństwa obywatelskiego, skupiony na kształtowaniu i wykorzystywaniu kapitału społecznego, na kreowaniu indywidualnych dróg rozwoju zawodowego" (s. 34).

red. Jan Zimny (Stalowa Wola: Katolicki Uniwersytet Lubelski Jana Pawła II, 2014); Edukacja na rozdrożu, red. Maria Szyszkowska (Białystok: Kresowa Agencja Wydawnicza, 2015).

2 Szerzej na ten temat: Szymański, Edukacyjne, 143-155.

3 Por. Stefan M. Kwiatkowski, Ksztatcenie zawodowe - wyzwania, priorytety, standar$d y$ (Warszawa: Instytut Badań Edukacyjnych, 2008). 
Druga część książki dotyka wybranych problemów zawodowych współczesnych nauczycieli ${ }^{4}$. Otwiera ją niezwykle interesujący artykuł Jarosława Michalskiego. Autor podjął w nim rozważania na temat improwizacji i taktu jako nieodłącznych komponentów pracy nauczyciela. Zwrócił uwagę na ich znaczenie w skutecznym działaniu nauczyciela oraz w procesie budowania przyjaznej i twórczej atmosfery podczas zajęć. Za szczególnie ważne należy uznać jego uwagi końcowe, z których wynika, że improwizacja nie może opierać się na kłamstwie czy zmyślaniu. Dlatego też istotne jest jej powiązanie z taktem pedagogicznym, ponieważ ,taki związek daje możliwość odwoływania się do wartości, do przeżywania rozmaitych wydarzeń, do dostrzegania dobrze rozumianego partnerstwa w procesie kształcenia" (s. 46). Artykuł Patrycji Jurkiewicz stanowi natomiast rzeczowy przegląd badań nad motywacją zawodową nauczycieli, dokonany na podstawie literatury anglojęzycznej. Autorka ustaliła, że w procesie formowania motywacji zawodowej kluczową rolę odgrywają czynniki emocjonalne, społeczne, organizacyjne i indywidualne. Kolejny tekst - przygotowany przez Jarosława Korczaka - został poświęcony charakterystyce zadań nauczyciela realizującego program zapobiegania uzależnieniom. Autor zwrócił uwagę na korzyści płynące z tworzenia i realizacji szkolnych programów profilaktycznych (z uwzględnieniem problematyki uzależnień). Wskazał również na trudności szkół, jakie wiążą się z opracowywaniem i wdrażaniem działań profilaktycznych. Drugą część książki zamyka artykuł Justyny Błaszczyk poruszający problemy, $\mathrm{z}$ jakimi zmaga się w swojej codziennej pracy pedagog szkolny (w tym przypadku skupiono się na problemach ucznia zaniedbanego przez jego rodziców). Autorka wskazała na możliwości psychologicznego i pedagogicznego wsparcia dziecka i jego rodziny, odwołała się przy tym do określonych regulacji prawnych. Co ważne, podkreśliła konieczność wprowadzenia zmian, które pozwoliłyby na usprawnienie systemu wsparcia uczniów zaniedbywanych (powinny one dotyczyć kwestii społecznych, prawnych i organizacyjnych).

Trzecią część publikacji - pt. „Pomiędzy polityką oświatową a systemem społeczno-gospodarczym" - otwiera opracowanie Anny Perkowskiej-Klejman i Anny Górki-Strzałkowskiej dotyczące sytuacji dzieci sze-

${ }^{4}$ Por. Wspótczesne problemy zawodu nauczyciela i pedagoga, red. Wanda Dróżka, Bożena Matyjas (Kielce: Wydawnictwo Uniwersytetu Humanistyczno-Przyrodniczego Jana Kochanowskiego, 2010); Szkoło, jaka jesteś? Problemy nauczycieli i uczniów we współczesnej szkole, red. Małgorzata Banasiak, Agata Wołowska (Warszawa: Wydawnictwo Difin SA, 2015). 
ścioletnich w szkole (na przykładzie Publicznej Szkoły Podstawowej nr 2 w Warce). Autorki w ciekawy sposób przybliżyły w nim dyskurs medialny odnoszący się do problemu obniżenia wieku szkolnego. Warte przeanalizowania są zaprezentowane przez nie wyniki badań ankietowych, których celem było poznanie opinii rodziców na temat obniżenia wieku szkolnego (w tym ich oczekiwań, nadziei i obaw, jakie wiążą się z funkcją opiekuńczo-wychowawczą szkoły w odniesieniu do uczniów w najmłodszym wieku). W kolejnym artykule - zatytułowanym „Polityczne (i nie tylko) spory o gimnazjum" - Błażej Przybylski, odwołując się do programów komitetów wyborczych oraz wypowiedzi polityków różnorakich opcji i uczonych zajmujących się problematyką edukacji, przytoczył i poddał rzetelnej analizie argumenty zwolenników i oponentów powrotu do dawnego systemu szkolnego. Michał Kwiatkowski zwrócił natomiast uwagę na rolę szkół wyższych w procesie przygotowywania kadr dla gospodarki. Wskazał na kompetencje, jakie powinien posiadać absolwent wyższej uczelni. Kolejny tekst - przygotowany przez Jarosławę Lach - został poświęcony wyzwaniom, przed którymi staje współczesna szkoła w kontekście dynamicznych zmian społecznych. Jak słusznie zauważyła Autorka, dzisiejsza „edukacja powinna wspierać jednostkę w odnalezieniu własnego miejsca w społeczeństwie, poszukiwaniu dróg rozwoju, krytycznego podejścia do zmieniającej się rzeczywistości. W świecie nowych wyzwań cywilizacyjnych każdy człowiek powinien być przygotowany do ciągłego doskonalenia się, zdobywania wiedzy i umiejętności zgodnie ze swoimi zainteresowaniami, możliwościami, ale z uwzględnieniem wymagań, jakie stawia rynek pracy" (s. 130). Z kolei Jakub Jerzy Czarkowski w interesujący sposób przedstawił koncepcję kształcenia komplementarnego, której istotę stanowi budowanie edukacji uwzględniającej przeobrażenia cywilizacyjne, edukacji elastycznej, atrakcyjnej i dostępnej dla wszystkich uczestników procesu kształcenia. Omawianą część pracy zamyka artykuł Jolanty Izabeli Wiśniewskiej poświęcony zagadnieniom teorii i praktyki edukacji dorosłych. Autorka podjęła w nim udaną próbę rozpoznania zarówno tych obszarów, w których teoria i praktyka edukacyjna są ze sobą spójne, jak i tych, w których występują między nimi istotne rozbieżności.

Artykuły składające się na czwartą część książki dotyczą wybranych problemów, jakim powinna sprostać współczesna edukacja. Kwestii wdrażania uczniów do samokształcenia przyjrzała się w swoim opracowaniu Marta Trusewicz-Pasikowska. Wskazała na działania, w tym konkretne zabiegi metodyczne, które pomagają w przygotowywaniu młodego człowieka do procesu samokształcenia. Jak słusznie stwierdziła, szkoła powinna „rozbu- 
dzić u uczniów ciekawość poznawczą oraz wyposażyć ich w warsztat umożliwiający im poznawanie nieustannie zmieniającego się świata" (s. 168). W kolejnym artykule Maja Wenderlich podjęła problem przygotowywania ludzi młodych do funkcjonowania w świecie wielokulturowym. Zwróciła uwagę na związek pomiędzy rozwijaniem kompetencji interkulturowych a nauczaniem języka obcego. Lekcje języka obcego ukazała jako swoistą okazję do poznania innych tradycji, zwyczajów, kultury. Z kolei Sylwia Galanciak poruszyła problem nowych technologii jako wsparcia dla edukacji (na przykładzie projektu „Cyfrowa szkoła”). Dokonała obszernej rekonstrukcji dyskursu polityczno-medialnego w tym obszarze. Kolejny artykuł - autorstwa Justyny Bluszcz - został poświęcony analizie zagadnień rozwoju zawodowego ucznia szkoły ogólnokształcącej w odniesieniu do podstawowych środowisk socjalizacyjnych, jakie są odpowiedzialne za jego wspieranie w procesie rozwoju zawodowego. Iwona Olszówka scharakteryzowała natomiast działalność Edukacyjnego Centrum Konsultacji przy Specjalnym Ośrodku Szkolno-Wychowawczym nr 1 w Częstochowie jako innowacyjnej formy wsparcia w systemie edukacji włączającej. Jak wykazała, działania inkluzyjne stwarzają nowe możliwości w zakresie włączania osób z niepełnosprawnością $\mathrm{w}$ ich naturalne środowisko życia. $\mathrm{W}$ ostatnim artykule Miłosz Wawrzyniec Romaniuk zaprezentował założenia Szkoły pod Żaglami jako instytucji realizującej ideę wychowania morskiego. Omówił proces kwalifikacji ludzi młodych do projektu oraz scharakteryzował sposób realizacji jego założeń podczas rejsu. Dowiódł, że wychowanie morskie stanowi czynnik wspomagający proces dojrzewania młodzieży. Szkołę pod Żaglami ukazał jako przykład inicjatywy spełniającej funkcję wychowawczą i profilaktyczną.

Niniejsza publikacja - obejmująca swym zakresem jedynie wybrane problemy współczesnej edukacji, podporządkowane kilku, dość ogólnie zakreślonym obszarom tematycznym - w wielu miejscach zachęca do dalszej dyskusji nad poruszonymi w niej kwestiami. Dotyczy to zwłaszcza rozważań na temat edukacyjnych wyzwań współczesności, które mogą skłaniać czytelnika do stawiania szeregu pytań o edukację człowieka w warunkach ponowoczesności, wdrażanie go do samokształcenia, rozwijanie jego kompetencji, a także pytań o różnorakie rozwiązania w sferze edukacji, jakie powinny odpowiadać potrzebom dynamicznie zmieniającego się świata. Taka była zresztą intencja redaktorów książki - wywołanie dyskusji. Jak podają we „Wstępie” Mirosław J. Szymański i Błażej Przybylski: „Przedstawione przez autorów opinie i punkty widzenia niekoniecznie muszą być podzielane i akceptowane. Jeśli okażą się kontrowersyjne, mogą stanowić zaczyn dal- 
szej dyskusji. Jeżeli publikacja przyczyni się do ożywienia takiej dyskusji, jej cel zostanie osiągnięty" (s. 11).

Autorzy poszczególnych artykułów, jeśli nawet nie zdołają wywołać żywych dyskusji, z pewnością przekonają wielu czytelników o tym, że edukacja to niezwykle istotny i nieodłączny komponent życia współczesnego człowieka, bez względu na fazę rozwojową, w której się on znajduje. Edukacja stanowi bowiem jedno z kluczowych zadań na całe życie (obejmuje swym zakresem zarówno uczenie się formalne - na wszystkich poziomach kształcenia, jak i uczenie się pozaformalne i nieformalne ${ }^{5}$ ). Szczególnie wymowny w tym kontekście wydaje się następujący fragment omawianej publikacji:

W coraz bardziej złożonej rzeczywistości społecznej nie można rozumieć świata i „być sobą" w tym świecie bez odpowiedniego poziomu wykształcenia i wiedzy. Człowiek niepojmujący otaczającej go rzeczywistości, nierozumiejący przemian społecznych, nieodczytujący wielu ważnych zjawisk współczesnej kultury staje się osobą wykluczoną, $[\ldots]$ skazaną na wegetację na peryferiach życia współczesnego (s. 7-8).

Dlatego też ważne jest przyjęcie szerokiego sposobu rozumienia edukacji jako procesu całożyciowego, ułatwiającego człowiekowi prowadzenie aktywnego życia ${ }^{6}$, również w okresie późnej dorosłości ${ }^{7}$.

5 Renata Konieczna-Woźniak, „Całożyciowe uczenie się z perspektywy zmieniającej się dorosłości człowieka i integracji pokoleń”, w: Młodość i starość. Integracja pokoleń, red. Beata Bugajska (Szczecin: ZAPOL, 2010), 147-148; Ewa Solarczyk-Ambrozik, „Uczenie się przez całe życie jako rzeczywistość edukacyjna. Dyskurs całożyciowego uczenia się w tle zmian społeczno-ekonomicznych”, w: Całożciowe uczenie się jako wyzwanie dla teorii i praktyki edukacyjnej, red. Ewa Solarczyk-Ambrozik (Poznań: Wydawnictwo Naukowe UAM, 2013), 27.

${ }^{6}$ Olga Czerniawska, Drogi i bezdroża andragogiki i gerontologii. Szkice i rozprawy (Łódź: Wydawnictwo Wyższej Szkoły Humanistyczno-Ekonomicznej, 2000), 180.

7 Jak zauważa Artur Fabiś: „Idea całożyciowego uczenia się coraz częściej odnajduje swoje praktyczne zastosowanie w okresie dorosłości [...]. Edukacja dorosłych, która skupiała się w przeszłości głównie na alfabetyzacji i edukacji elementarnej niewykształconych dorosłych robotników, obecnie ma dużo dalej idące zadania i cele oraz rozciąga się na całe życie, także w starości”. Artur Fabiś, „Edukacja osób starszych”, w: Artur Fabiś, Joanna K. Wawrzyniak, Agata Chabior, Ludzka starość. Wybrane zagadnienia gerontologii społecznej (Kraków: Oficyna Wydawnicza „Impuls”, 2015), 171. Por. Magdalena Pakuła, Postawy osób starszych wobec edukacji. Studium teoretyczno-diagnostyczne (Lublin: Wydawnictwo Uniwersytetu Marii Curie-Skłodowskiej, 2010), 59-64; Tomasz Różański, „Educational activity of older people in Poland - selected issues", w: Society. Integration. Education, t. 4, red. 
Książka liczy 254 strony. Ma przejrzystą strukturę i napisana jest zrozumiałym językiem. Lekturę składających się na nią artykułów ułatwiają wykazy literatury i stron internetowych. Pewnym mankamentem publikacji jest brak informacji o autorach poszczególnych opracowań.

Podsumowując, należy stwierdzić, że recenzowana praca stanowi interesujące i rzeczowo przygotowane źródło informacji na temat ważnych problemów współczesnej edukacji. Mimo że porusza wybrane kwestie, znacząco wzbogaca dyskusję naukową w wielu obszarach, nie tylko istotnych dla pedagogiki. Książkę tę warto polecić badaczom, pedagogom, nauczycielom, studentom kierunków humanistycznych i społecznych, a także osobom zajmującym się organizacją sytemu edukacji w naszym kraju.

Tomasz Różański*

\section{Bibliografia}

Czerniawska, Olga. Drogi i bezdroża andragogiki i gerontologii. Szkice i rozprawy.

Łódź: Wydawnictwo Wyższej Szkoły Humanistyczno-Ekonomicznej, 2000.

Edukacja na rozdrożu, red. Maria Szyszkowska. Białystok: Kresowa Agencja Wydawnicza, 2015.

Fabiś, Artur. „Edukacja osób starszych”. W: Artur Fabiś, Joanna K. Wawrzyniak, Agata Chabior, Ludzka starość. Wybrane zagadnienia gerontologii społecznej, 171-198. Kraków: Oficyna Wydawnicza „Impuls”, 2015.

Konieczna-Woźniak, Renata. „Całożyciowe uczenie się z perspektywy zmieniającej się dorosłości człowieka i integracji pokoleń”. W: Młodość i starość. Integracja pokoleń, red. Beata Bugajska, 145-157. Szczecin: ZAPOL, 2010.

Kwiatkowski, Stefan M. Kształcenie zawodowe - wyzwania, priorytety, standardy.

Warszawa: Instytut Badań Edukacyjnych, 2008.

Oblicza edukacji w zmieniajacym się społeczeństwie, red. Agata Popławska. Białystok: Wydawnictwo Niepaństwowej Wyższej Szkoły Pedagogicznej, 2012.

Pakuła, Magdalena. Postawy osób starszych wobec edukacji. Studium teoretyczno-diagnostyczne. Lublin: Wydawnictwo Uniwersytetu Marii Curie-Skłodowskiej, 2010.

Velta Lubkina, Svetlana Usca, Anda Zvaigzne (Rezekne: Rezekne Academy of Technologies, 2016), 122-131.

* Dr Tomasz Różański jest adiunktem w Katedrze Socjologii Edukacji i Pedagogiki Społecznej na Wydziale Nauk Pedagogicznych Uniwersytetu Mikołaja Kopernika w Toruniu. Adres: Wydział Nauk Pedagogicznych UMK, ul. Lwowska 1, 87-100 Toruń; e-mail: tomrozan1@umk.pl. 
Problemy edukacji jutra $w$ dobie globalizacji, red. Kazimierz Denek, Aleksandra Kamińska, Piotr Oleśniewicz. Sosnowiec: Oficyna Wydawnicza „Humanitas”, 2012.

Problemy edukacji w społeczeństwie wiedzy, red. Stanisław Juszczyk. Katowice: Wydawnictwo Uniwersytetu Śląskiego, 2012.

Różański, Tomasz. „Educational activity of older people in Poland - selected issues". W: Society. Integration. Education, t. 4, red. Velta Lubkina, Svetlana Usca, Anda Zvaigzne, 122-131. Rezekne: Rezekne Academy of Technologies, 2016.

Solarczyk-Ambrozik, Ewa. „Uczenie się przez całe życie jako rzeczywistość edukacyjna. Dyskurs całożyciowego uczenia się w tle zmian społeczno-ekonomicznych". W: Całożyciowe uczenie się jako wyzwanie dla teorii i praktyki edukacyjnej, red. Ewa Solarczyk-Ambrozik, 11-35. Poznań: Wydawnictwo Naukowe UAM, 2013.

Szkoło, jaka jesteś? Problemy nauczycieli i uczniów we współczesnej szkole, red. Małgorzata Banasiak, Agata Wołowska. Warszawa: Wydawnictwo Difin SA, 2015.

Szymański, Mirosław J. Edukacyjne problemy współczesności. Kraków-Warszawa: Oficyna Wydawnicza „Impuls”, 2014.

W kręgu współczesnych problemów edukacyjnych, red. Mirosław J. Szymański, Błażej Przybylski. Warszawa: Wydawnictwo Akademii Pedagogiki Specjalnej im. Marii Grzegorzewskiej, 2015.

Wspótczesne problemy edukacji w Polsce, red. Jan Zimny. Stalowa Wola: Katolicki Uniwersytet Lubelski Jana Pawła II, 2014.

Wspótczesne problemy zawodu nauczyciela i pedagoga, red. Wanda Dróżka, Bożena Matyjas. Kielce: Wydawnictwo Uniwersytetu Humanistyczno-Przyrodniczego Jana Kochanowskiego, 2010.

\section{Tomasz Biernat, Katarzyna Kuziak, Jan Malinowski (red.), Rodzina w pracy socjalnej - pomoc w sytuacjach trudnych i kryzysowych, Toruń: Wydawnictwo Edukacyjne „Akapit”, 2016, s. 384.}

DOl: http://dx.doi.org/10.12775/PCh.2017.022

Rodzina jako najstarsza i podstawowa grupa społeczna, stanowiąca naturalny i jednocześnie nieodłączny element struktury społecznej, nazywana 